\title{
Spatial and seasonal variation of zooplankton assemblages in two tidal control structures in Northeastern Brazil
}

\author{
Variação espacial e sazonal das assembleias do zooplâncton em duas estruturas de controle de \\ marés no Nordeste do Brasil \\ Variación espacial y estacional de conjuntos de zooplancton en dos estructuras de control de \\ mareas en el Noreste de Brasil
}

Received: 08/31/2021 | Reviewed: 09/06/2021 | Accept: 09/14/2021 | Published: 09/15/2021

Yago Bruno Silveira Nunes

ORCID: https://orcid.org/0000-0002-0890-1730 Universidade Estadual do Maranhão, Brazil E-mail: ybruno3098@gmail.com

Ladilson Rodrigues Silva

ORCID: https://orcid.org/0000-0001-7388-5709

Universidade Estadual do Maranhão, Brazil E-mail: ladilsonrodrigues341@gmail.com

Amanda Lorena Lima Oliveira ORCID: https://orcid.org/0000-0002-9059-7415

Universidade Federal do Maranhão, Brazil E-mail: amandalimaa2792@gmail.com

Marina Bezerra Figueiredo

ORCID: https://orcid.org/0000-0001-7485-8593 Universidade Estadual do Maranhão, Brazil E-mail: figmarina@gmail.com

\begin{abstract}
Zooplankton is a group of organisms that can help to understand the quality of aquatic ecosystems, as they are responsible for transforming energy matter, thus making it available to other links, making them important in aquatic trophodynamics. This study analyzed spatial and temporal variations in zooplankton communities found in two tidal control structures on Ilha do Maranhão, northeastern Brazil. Sampling took place from September 2017 to July 2018. Abiotic parameters (temperature, salinity, and transparency) and plankton samples were recorded monthly throughout the study period at each sampling site. The results found for the abiotic parameters showed a well-defined pattern, with a clear division between the dry and rainy periods. Forty taxa represented the zooplankton community of the São Luís tidal control structure, and from São José de Ribamar by 21 taxa, represented mainly by copepods, ichthyoplankton, foraminifera, polychaetes, and mollusks. The analysis of ecological indices of richness, evenness, and diversity showed a difference in the distribution of organisms among the study areas. We identified an important influence of the physicochemical parameters on the zooplankton communities of São Luís and São José de Ribamar, according to the statistical analyzes used in this study.
\end{abstract}

Keywords: Copepods; Coastal dam; Aquatic communities; Marine plankton.

\section{Resumo}

O zooplâncton é um grupo de organismos que podem ajudar a entender a qualidade dos ecossistemas aquáticos, pois são responsáveis por transformar a matéria energética, dessa forma disponibilizar para outras elos, tornando-os importantes na trofodinâmica aquática. Este estudo analisou variações espaciais e temporais nas comunidades zooplanctônicas encontradas em duas estruturas de controle de marés na Ilha do Maranhão, nordeste do Brasil. A amostragem ocorreu durante os meses de setembro de 2017 a julho de 2018. Os parâmetros abióticos (temperatura, salinidade e transparência) e as amostras de plâncton foram registradas mensalmente durante todo o período do estudo em cada local de amostragem. Os resultados encontrados para os parâmetros abióticos mostraram um padrão bem definido, com uma divisão clara entre os períodos seco e chuvoso. A comunidade zooplanctônica da estrutura de controle de marés de São Luís foi representada por 40 táxons, e de São José de Ribamar por 21 táxons, representados principalmente por copépodes, ictioplâncton, foraminíferos, poliquetas e moluscos. A análise dos índices ecológicos de riqueza, equitabilidade e diversidade mostrou que houve uma diferença na distribuição dos organismos entre as áreas de estudo. Identificamos uma influência importante dos parâmetros físico-químicos sobre as comunidades zooplanctônicas de São Luís e São José de Ribamar, de acordo com as análises estatísticas utilizadas neste estudo.

Palavras-chave: Copépodos; Espigão costeiro; Comunidades aquáticas; Plâncton marinho. 


\section{Resumen}

El zooplancton es un grupo de organismos que pueden ayudar a comprender la calidad de los ecosistemas acuáticos, ya que son los encargados de transformar la materia energética, poniéndolos a disposición de otros enlaces, haciéndolos importantes en la trofodinámica acuática. Este estudio analizó las variaciones espaciales y temporales en las comunidades de zooplancton encontradas en dos estructuras de control de mareas en la Isla del Maranhão, noreste de Brasil. El muestreo se llevó a cabo entre septiembre de 2017 y julio de 2018. Los parámetros abióticos (temperatura, salinidad y transparencia) y las muestras de plancton se registraron mensualmente durante todo el período de estudio en cada sitio de muestreo. Los resultados encontrados para los parámetros abióticos mostraron un patrón bien definido, con una clara división entre los períodos secos y lluviosos. La comunidad de zooplancton de la estructura de control de mareas de São Luís estuvo representada por 40 taxones, y de São José de Ribamar por 21 taxones, representados principalmente por copépodos, ictioplancton, foraminíferos, poliquetos y moluscos. El análisis de los índices ecológicos de riqueza, uniformidad y diversidad mostró que había una diferencia en la distribución de organismos entre las áreas de estudio. Identificamos una influencia importante de los parámetros fisicoquímicos en las comunidades de zooplancton de São Luís y São José de Ribamar, según los análisis estadísticos utilizados en este estudio.

Palabras clave: Copépodos; Estructura de contención costera; Comunidades acuáticas; Plancton marino.

\section{Introduction}

Marine currents have been causing erosion in Brazilian coastal zones, and tide-control structures are constructed to minimize impacts (Souza, 2009; Paula, 2015). This also occurs due to growing and disorderly real estate speculation in coastal regions that increase pressure on the marine environment (Marcus, 2004; Nunes et al., 2018).

To contain the advance of the sea and protect coastal construction, tide-control structures are built with high or low structural technology (Paula, 2015). These tide-control structures are constructed to contain coastal erosion, which occurs when the sea advances on land, causing erosion and retreat of the coastline (Barra et al., 2018). In some cases, tide control structures are also used as attractions.

These constructions can impair the distribution of aquatic organisms and physical, chemical processes (Ziober \& Zanirato, 2014; Webber et al., 2005). Biomonitoring using zooplankton helps to understand these environments better since zooplankton is directly associated with the physical, chemical, and biological characteristics of water, such as nutrient concentrations, $\mathrm{pH}$, salinity, and temperature influence the composition and abundance of zooplankton (Vieira \& Dantas, 2015). Considering spatial and seasonal variations and environmental impacts on the trophic web, as well as distribution, life cycle, size, some zooplanktonic organisms can be used as indicators to determine the ecological status and environmental health of a region (Porto Neto et al., 1999; Richardson, 2008; Mackas et al., 2012; Souza, 2019).

There are no previous studies about the impacts of tide-control structures on the marine fauna and flora in the region, making it hard to analyze possible changes. The tide-control structures at São Luís and São José de Ribamar were chosen as study areas because there have been more changes in their coastal environments over the years. At the São Luís tide-control structure, the non-containment zone accumulates a high amount of sand, which can change the region's dynamics and the organisms found. Meanwhile, in São José de Ribamar, there is a high accumulation of organic matter in the substrate of the containment zone.

Recognizing that for the marine environment, this information on the relationship between sea containment structures and zooplankton and distribution communities is limited, this study analyzed the distribution spatial and seasonal characterization of zooplankton assemblages at two tide-control structures on Maranhão Island in Northeastern Brazil to increase knowledge about these communities, and verify how these structures can affect the distribution and abundance of these organisms.

\section{Methodology}

The samples were taken in the tidal containment regions, located in the municipalities of São José de Ribamar

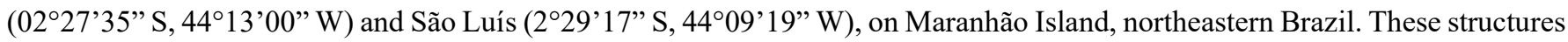


were completed in 2014. Each study area had two sampling points, with P01 representing the tidal containment zone and P02 the non-containment region (Figure 1). In the P01 zone, due to the interference caused by the barrier, there is not a great mixture of water, the organisms remaining concentrated in a more closed region. In the P02 zone, because it is open, there is a greater flow dynamic of the organisms, this region being considered without impact. The relief of the Maranhão state reentrances favors a wide range of tides and semi-tides, which vary from 0.0 to $7.2 \mathrm{~m}$, with complex and dynamic oceanographic characteristics (El-Robrini et al., 2015; Masullo, 2016).

Figure 1. Location of the collection points at the São Luís and São José de Ribamar tide-control structure - MA.
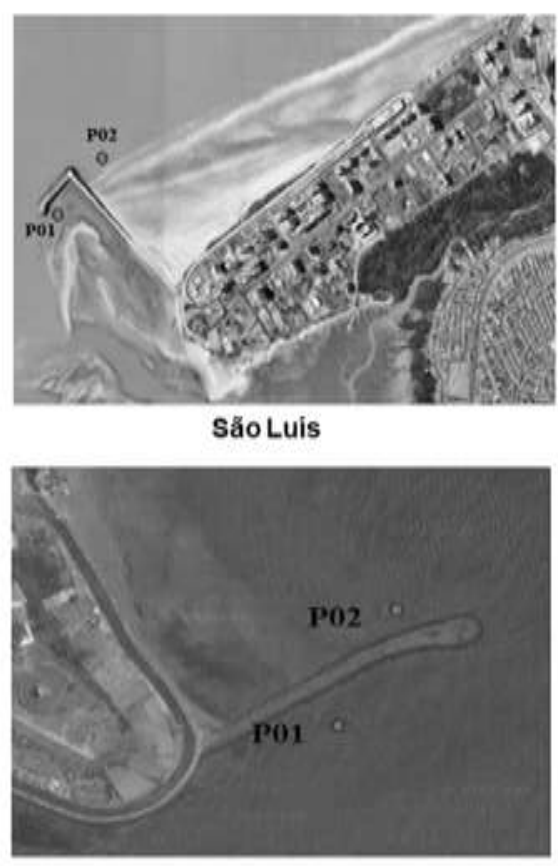

Săo José de Ribamar

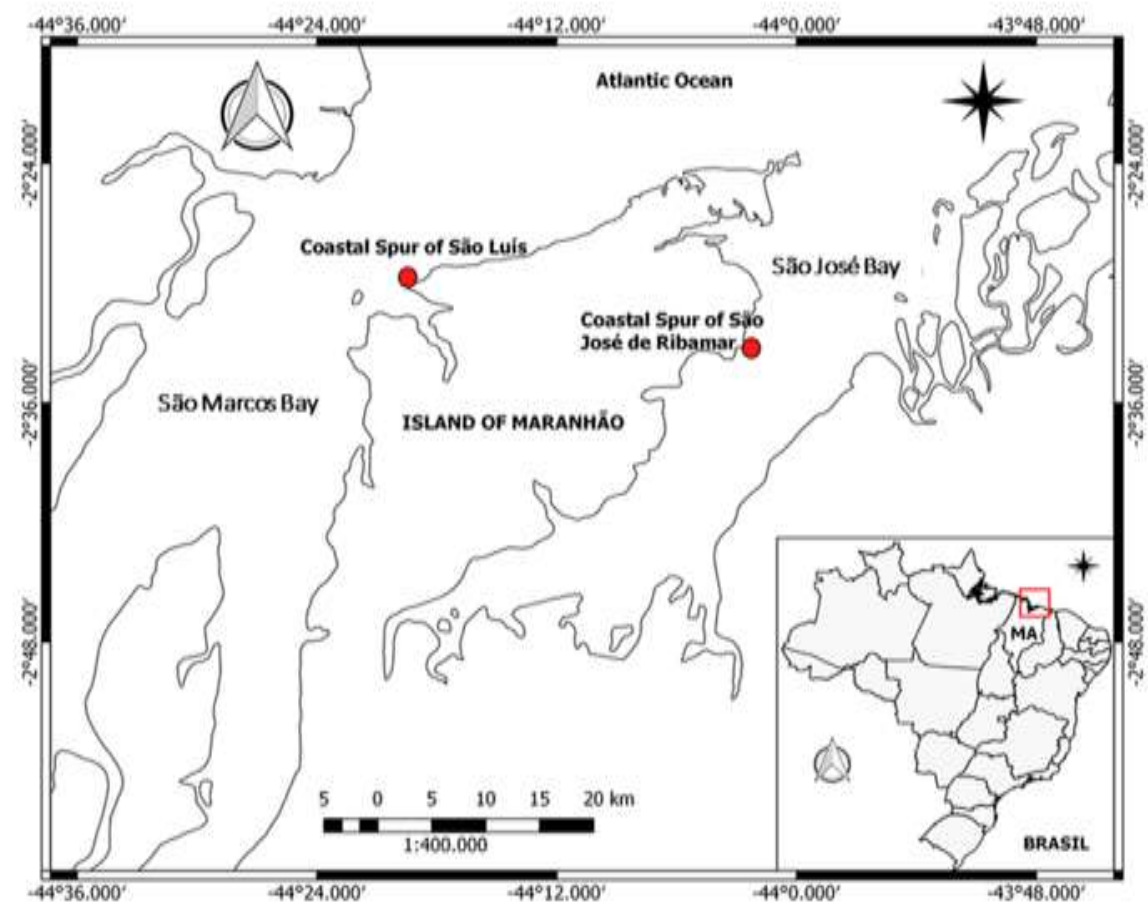

Source: Authors.

\section{Abiotic and biological sampling}

Monthly campaigns were conducted in the tidal containment zone during the dry season, from September to December 2017, and in the rainy season, from January to July 2018, totaling 22 collections in the two study areas. The physicochemical parameters were recorded monthly with a refractometer, thermometer, and Secchi disk to measure salinity, temperature, and water transparency, respectively. The accumulated rainfall data for 2017 and 2018 were obtained from the National Institute of Meteorology - INMET (http://www.inmet.gov.br) database for each collection month.

Plankton samples were collected at the subsurface of the water column using conical-cylindrical plankton nets with two meshes: 120 and $300 \mu \mathrm{m}$. The manual drag lasted 10 minutes in each area. Afterward, the samples were fixed with $4 \%$ formaldehyde. For each sample, a $6 \mathrm{~mL}$ aliquot was collected for the counted subjects using a Sedgewick-Rafter chamber, after which they were taken to a stereoscopic microscope and optical microscope for the lowest possible taxonomic level, following the specialized literature (Boltovskoy, 1999; Bradford et al., 1999; Bonecker, 2006). The organisms were identified with the lowest possible taxonomic level. Protocol 043/2018 of the Ethics Committee on animal use of the State University of Maranhão was respected. 


\section{Numerical and statistical treatment}

The density analysis was calculated using the formula $\mathrm{D}=\mathrm{N} / \mathrm{V}$, where $\mathrm{N}$ is the number of organisms in the subsamples and $\mathrm{V}$ is the volume of filtered water. The volume of filtered water (using a flowmeter of water) was obtained with the formula $\mathrm{V}=a \times n \times c$, where " $a$ " is the area of the mouth of the network, " $n$ " is the variation of the number of rotations of the flowmeter and " $c$ " is the factor of calibration (0.3). The result was given in org. $\mathrm{m}^{-3}$.

Ecological indices were used to explain the seasonal and spatial behavior of the zooplanktonic organisms in the study regions. Diversity was determined according to Shannon-Wienner (1963), $\mathrm{H}^{\prime}=-\Sigma \mathrm{pi} \times \log 2 \mathrm{pi}\left(\mathrm{H}^{\prime}=\right.$ Specific diversity - $\mathrm{Pi}$ is the proportion of the species given by ni/N (Number of individuals (ni) of taxa by the total number of organisms (N)) to identify how the species varied in the study areas. The specific richness used was that proposed by Margalef (1958) to determine the number of organisms $\mathrm{D}=(\mathrm{S}-1) / \log \mathrm{N}(\mathrm{S}=$ total number of species present in the sample; $\log =\log$ in base $2 ; \mathrm{N}=$ total number of individuals in the sample). The Pielou Equity Indices (1966) were calculated to identify the distribution of individuals among species $J^{\prime}=J^{\prime}=H^{\prime} / H^{\prime}$ máx $\left(J{ }^{\prime}=\right.$ the equitability index; $H^{\prime}=$ the calculated diversity index; H'max = given by the formula following: $\mathrm{H}^{\prime} / \log 2 \mathrm{~S}-\mathrm{S}=$ number of species in each sample).

The constancy indexes used were those described by Dajoz (1983), in which the zooplanktonic organisms were considered "Constant" when registered in more than $50 \%$ of the samples, "Accessory" when found in 25 - 50\% of the samples, and "Accidental" when recorded in less than $25 \%$ of the samples.

The Shapiro-Wilk and Levene test was used to test the normality and homogeneity of the abiotic and biological data variances. We applied a one-way analysis of variance (one-way ANOVA) with the normal data. For variables (were points P1 and P2 grouped to make a comparison between the two periods (seasonal) and between structures (spatial)) that did not meet the one-way ANOVA assumption, the Kruskal-Wallis test was applied, with significant differences considered to be $\mathrm{p}<0.05$. The Principal Components Analysis (PCA) was performed using Pearson's linear moment-product correlation, revealing and hierarchizing the factors responsible for the data's variance, including zooplankton occurrence and hydrological parameters. The similarity matrix was based on the Euclidian distance was applied to determine the similarity of the sampling points in relation to the environmental parameters. The Canonical Correspondence Analysis (CCA) was applied to correlate the environmental variables with the abundant groups/species. The statistical analyses were performed with the Past 3.14, STATISTICA 10.0, and PRIMER (version 6.0) software.

\section{Results}

\section{Physical-chemical parameters}

The physical-defined characteristics of the studied variables are summarized in Table 1. The surface temperature (SST) does not present significant differences; however, Secchi, salinity, and rain registered significant differences throughout the study. According to the one-way ANOVA, the sea surface temperature showed no significant seasonal and spatial variation ( $\mathrm{p}<$ 0.05) in either São Luís or São José de Ribamar. 
Table 1. Physical-chemical data collected during dry and rainy periods in the tidal containment areas. Legend: * Indicates significant stationary and spatial variation of salinity for São Luís and São José de Ribamar (p < 0.05 ANOVA one-way); ** Indicates significant stationary and spatial variation of transparency for São Luís and São José de Ribamar (p < 0.05 ANOVA one-way).

\begin{tabular}{lccccc}
\hline \multirow{2}{*}{ Parameters } & \multirow{2}{*}{ Unit. } & \multicolumn{2}{c}{ Dry season } & \multicolumn{2}{c}{ Rainy season } \\
\cline { 3 - 6 } & & P01 & P02 & P01 & P02 \\
\hline Sea surface temperature & ${ }^{\circ} \mathrm{C}$ & $28.2 \pm 0.8$ & $28.7 \pm 1.4$ & $29 \pm 1.1$ & $28.4 \pm 0.9$ \\
Salinity & - & $33.2 \pm 1.7^{*}$ & $31.9 \pm 3.3^{*}$ & $27.7 \pm 4.2^{*}$ & $24.6 \pm 3.0^{*}$ \\
Secchi & $\mathrm{cm}$ & $9.8 \pm 2.4^{* *}$ & $25.5 \pm 1.8^{* *}$ & $19.3 \pm 9.8^{* *}$ & $26.9 \pm 2.3^{* *}$ \\
Rainfall & $\mathrm{mm}$ & $16.4 \pm 27.0$ & $16.4 \pm 27.0$ & $295.1 \pm 162.1$ & $295.1 \pm 162.1$ \\
\hline
\end{tabular}

Source: Authors.

\section{Zooplankton assemblage}

The zooplankton communities at the tide-control structures were represented by 40 taxa in São Luís and 21 in São José de Ribamar (Table 2), comprised mainly of copepods, ichthyoplankton, foraminifera, Polychaeta, mollusks, and mysids. The organisms of the São Luís tidal containment zone had a significant variation in the constancy indexes (Table 2) between the seasonal periods, with a total of 40 species classified as accidental during the dry season. No constancy between the zooplankton groups was noticed in the rainy season, with $12.5 \%$ of the organisms characterized as accessory and $87.5 \%$ as accidental. According to the one-way ANOVA $(\mathrm{p}<0.05)$, there was no variation in the abundance of organisms between the seasonal periods. During the dry season, the zooplankton organisms at the São José de Ribamar tide-control structure were classified as accessory (81\%) and accidental (19\%). However, in the rainy season, this changed to 57\% accidental, 24\% constant, and $19 \%$ accessory (Table 2). There was variation in the number of organisms between the seasonal periods ( $<<0.05$, ANOVA one-way).

In terms of density (Figure 2), it was possible to notice that in São José de Ribamar, February had the highest density at P01 with 196.2 org. $\mathrm{m}^{-3}$, and at P02, it was calculated at 175.3 org. $\mathrm{m}^{-3}$. The density of the zooplanktonic organisms at the São Luís tide-control structure was extremely high in January (point P01) and February (point P02) (372.3 org.m ${ }^{-3}$ with containment and 642.3 org. $\mathrm{m}^{-3}$ without containment). The São Luís and São José de Ribamar tide-control structures displayed significant spatial and temporal variations ( $\mathrm{p}<0.05$, one-way ANOVA).

Figure 2. Density of zooplanktonic organisms of (A) São Luís and (B) São José de Ribamar. org.m3 - organism per cubic meter.

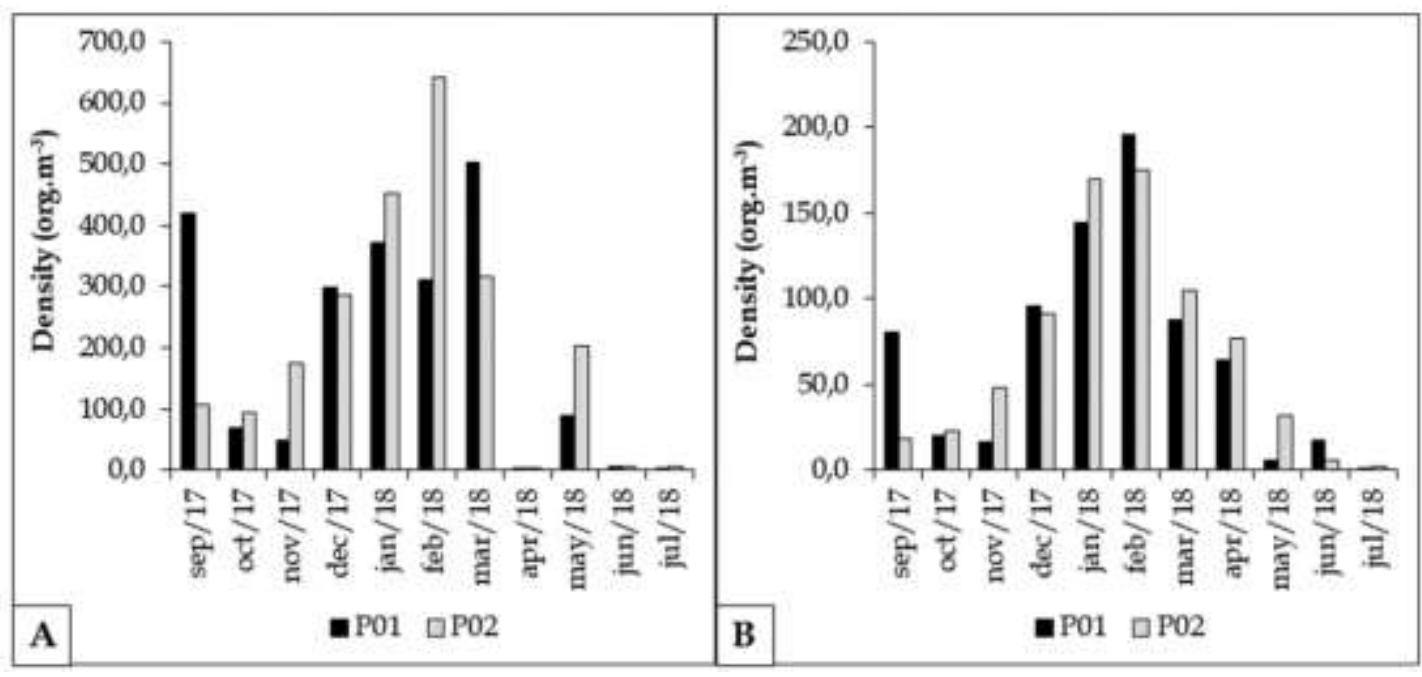

Source: Authors. 
Table 2. Taxonomic synopsis of the zooplankton of the Coastal tide-control of São Luís and São José de Ribamar - MA, between the periods analyzed.

\begin{tabular}{|c|c|c|c|c|c|c|c|c|c|c|c|c|}
\hline \multirow{3}{*}{ GROUPS and SPECIES } & \multicolumn{6}{|c|}{ São Luís } & \multicolumn{6}{|c|}{ São José de Ribamar } \\
\hline & \multicolumn{3}{|c|}{ Dry } & \multicolumn{3}{|c|}{ Rainy } & \multicolumn{3}{|c|}{ Dry } & \multicolumn{3}{|c|}{ Rainy } \\
\hline & DEN (org.m ${ }^{-3}$ ) & TO $(\%)$ & $\mathrm{CI}$ & DEN (org.m ${ }^{-3}$ ) & TO $(\%)$ & $\mathbf{C I}$ & DEN (org.m $\left.{ }^{-3}\right)$ & TO $(\%)$ & CI & DEN (org.m ${ }^{-3}$ ) & TO $(\%)$ & CI \\
\hline \multicolumn{13}{|l|}{ FORAMINIFERA } \\
\hline Ammonia beccarii Linnaeus, 1758 & 130 & 5 & Ac & 288 & 5.1 & Ac & 0 & 0 & Ac & 0 & 0 & Ac \\
\hline Ammonia sp. Brünnich, 1771 & 128 & 5 & Ac & 283 & 4 & Ac & 0 & 0 & Ac & 0 & 0 & Ac \\
\hline \multicolumn{13}{|l|}{ CNIDARIA } \\
\hline Hydrozoa & 6 & 2.5 & Ac & 1 & 0.6 & Ac & 1 & 1.8 & Ac & 0 & 0 & Ac \\
\hline Hydromedusa & 2 & 1.2 & Ac & 4 & 2.3 & Ac & 6 & 3.6 & Ac & 0 & 0 & Ac \\
\hline \multicolumn{13}{|l|}{ MOLLUSKS } \\
\hline Gastropoda (veliger) & 56 & 3.7 & Ac & 20 & 3.4 & Ac & 1 & 1.8 & Ac & 0 & 0 & Ac \\
\hline Bivalve (veliger) & 104 & 3.7 & Ac & 309 & 4.5 & Ac & 3 & 1.8 & Ac & 10 & 3.0 & Ac \\
\hline \multicolumn{13}{|l|}{ COPEPODS } \\
\hline Acartia lilljeborgi Giesbrecht, 1892 & 359 & 5 & Ac & 348 & 6.8 & $\mathrm{~A}$ & 177 & 14.5 & A & 89 & 12.0 & $\mathrm{C}$ \\
\hline Acartia tonsa Giesbrecht, 1892 & 436 & 5 & Ac & 311 & 6.8 & A & 75 & 14.5 & A & 67 & 12.0 & $\mathrm{C}$ \\
\hline Centropages velificatus Oliveira, 1947 & 175 & 5 & Ac & 44 & 4 & Ac & 0 & 0 & Ac & 61 & 8.0 & A \\
\hline Parvocalanus crassirostris Dahl F., 1894 & 0 & 0 & Ac & 0 & 0 & Ac & 14 & 3.6 & Ac & 229 & 14.0 & $\mathrm{C}$ \\
\hline Paracalanus sp. Giesbrecht, 1893 & 43 & 5 & Ac & 14 & 2.3 & Ac & 0 & 0 & Ac & 0 & 0 & Ac \\
\hline Temora turbinata Dana, 1849 & 59 & 5 & Ac & 39 & 1.7 & Ac & 0 & 0 & Ac & 0 & 0 & Ac \\
\hline Oithona similes Claus, 1863 & 12 & 2.5 & Ac & 25 & 4 & Ac & 0 & 0 & Ac & 294 & 14.0 & $\mathrm{C}$ \\
\hline Oithona sp. Baird, 1843 & 0 & 0 & Ac & 0 & 0 & Ac & 0 & 0 & Ac & 7 & 6.0 & A \\
\hline Euterpina acutifrons Dana, 1848 & 259 & 5 & Ac & 371 & 6.8 & A & 0 & 0 & Ac & 141 & 11.0 & $\mathrm{C}$ \\
\hline Euterpina sp. Norman, 1903 & 0 & 0 & Ac & 0 & 0 & Ac & 0 & 0 & Ac & 10 & 6.0 & A \\
\hline Corycaeus giesbrechti Dahl, 1894 & 2 & 1.2 & Ac & 2 & 1.1 & Ac & 0 & 0 & Ac & 0 & 0 & Ac \\
\hline Copepoda Nauplios & 43 & 5 & Ac & 178 & 6.8 & A & 0 & 0 & Ac & 0 & 0 & Ac \\
\hline \multicolumn{13}{|l|}{ MALACOSTRACA } \\
\hline Belzebub faxoni Borradaile, 1915 & 12 & 3.7 & Ac & 8 & 1.7 & Ac & 0 & 0 & Ac & 0 & 0 & Ac \\
\hline Mysids & 12 & 2.5 & Ac & 19 & 2.8 & Ac & 0 & 0 & Ac & 0 & 0 & Ac \\
\hline Brachyura (zoea) & 9 & 3.7 & $\mathrm{Ac}$ & 3 & 1.7 & $\mathrm{Ac}$ & 354 & 14.5 & A & 45 & 8.0 & A \\
\hline
\end{tabular}


Isopoda

Amphipoda

Cumacea

\section{ANNELIDA}

Polychaeta (just)

Polychaeta (larvae)

\section{CHAETOGNATHA}

Sagittidae sp. Quoy \& Gaimard, 1827

\section{APPENDICULARIA}

Oikopleura dioica Fol, 1872

\section{ICHTHYOPLANKTON}

Sardinella brasiliensis Steindachner, 1879

Anchoviella lepidentostole Fowler, 1911

Anchovia clupeoides Swainson, 1839

Oligoplites saurus Gill, 1863

Achirus achirus Linnaeus, 1758

Achirus sp. Linnaeus, 1758

Chloroscombrus crhysurus Linnaeus, 1766

Lycengraulis sp. Spix \& Agassiz, 1829

Conodon nobilis Linnaeus, 1758

Sphoeroides testudine Linnaeus, 1758

Elops saurus Linnaeus, 1766

Lutijanus jocu Bloch \& Schneider, 1801

Fish eggs

\section{OTHERS}

Ostracoda

Nematode

Radiolaria

Insects

Total

$\begin{array}{ccc}1 & 0.6 & \text { Ac } \\ 2 & 1.2 & \text { Ac } \\ 1 & 0.6 & \text { Ac } \\ & & \\ 25 & 3.7 & \text { Ac } \\ 8 & 1.2 & \text { Ac }\end{array}$

$11 \quad 5 \quad$ Ac

16

0.6 Ac

$2.5 \quad$ Ac

1.2 Ac

0.6 Ac

$2.5 \quad \mathrm{Ac}$

1.8 Ac

$1.2 \mathrm{Ac}$

0.6 Ac

0.6 Ac

0.6 Ac

0 Ac

$0 \quad$ Ac

0.6 Ac

0 Ac
30

$21 \quad 0.6 \quad$ Ac

1

2

36
26

\section{1}

7

7
3
1

3
1

1
3

3
1

1
4

4
0

0
2

2
2

2
1

1
4
1

0

6

62.8

$\begin{array}{ll}0.6 & \mathrm{Ac} \\ 0.6 & \mathrm{Ac}\end{array}$

1.1 Ac

5.1 Ac

5.1 Ac

$5.6 \quad$ A

0.6 Ac

2.3 Ac

1.7 Ac

0.6 Ac

1.7 Ac

0.6 Ac

1.1 Ac

1.1
0

1.1 Ac

1.1 Ac

0.6 Ac

0.6 Ac

0.6 Ac

0 Ac

$2.8 \quad$ Ac

0.6 Ac

$\begin{array}{cc}0.6 & \text { Ac } \\ 0 & \text { Ac }\end{array}$

$\begin{array}{cc}0 & \text { Ac } \\ 100 & -\end{array}$

$0 \quad 0 \quad$ Ac

0

0

47

0

0

0

0 Ac

0

2

0

2421

100

\begin{tabular}{cccccc}
29 & 7.3 & Ac & 0 & 0 & Ac \\
0 & 0 & Ac & 0 & 0 & Ac \\
0 & 0 & Ac & 0 & 0 & Ac \\
0 & 0 & Ac & 0 & 0 & Ac \\
12 & 7.3 & Ac & 0 & 0 & Ac \\
0 & 0 & Ac & 0 & 0 & Ac \\
0 & 0 & Ac & 0 & 0 & Ac \\
0 & 0 & Ac & 0 & 0 & Ac \\
0 & 0 & Ac & 0 & 0 & Ac \\
0 & 0 & Ac & 0 & 0 & Ac \\
0 & 0 & Ac & 0 & 0 & Ac \\
0 & 0 & Ac & 0 & 0 & Ac \\
6 & 5.5 & Ac & 0 & 0 & Ac \\
& & & & & \\
0 & 0 & Ac & 2 & 2.0 & Ac \\
3 & 3.6 & Ac & 1 & 1.0 & Ac \\
0 & 0 & Ac & 0 & 0 & Ac \\
7 & 5.5 & Ac & 0 & 0 & Ac \\
\hline $\mathbf{7 3 5}$ & $\mathbf{1 0 0}$ & - & $\mathbf{9 6 0}$ & $\mathbf{1 0 0}$ & - \\
\hline
\end{tabular}

. Legend: DEN - Density (Org. $\mathrm{m}^{-3}$ - organism per cubic meter); TO - Total Occurrence; CI - constancy indices (Ac - Accidental; A - accessory; C - constant).Source: Authors. 


\section{Ecological Indexes}

The ecological indexes show that throughout the study period, the average diversity during the dry season in São Luís

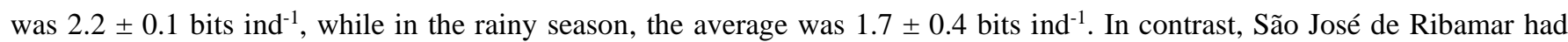

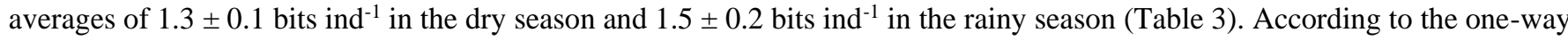
ANOVA, the diversity showed significant seasonal and spatial variation $(\mathrm{p}<0.05)$ in both study areas.

Table 3. Ecological indices of dry and rainy periods in tide-control containment areas.

\begin{tabular}{lccccc}
\hline \multirow{2}{*}{$\begin{array}{c}\text { Ecological } \\
\text { indices }\end{array}$} & Unit. & \multicolumn{2}{c}{ Dry } & \multicolumn{2}{c}{ Rainy } \\
\cline { 3 - 6 } & & P01 & P02 & P01 & P02 \\
\hline Diversity & Bits ind $^{-1}$ & $2.2 \pm 0.1$ & $1.3 \pm 0.1$ & $1.7 \pm 0.4$ & $1.5 \pm 0.2$ \\
Richness & Bits ind $^{-1}$ & $1.3 \pm 0.2^{*}$ & $1.3 \pm 0.2^{*}$ & $1.0 \pm 0.2^{*}$ & $1.5 \pm 0.4^{*}$ \\
Equitability & - & $0.7 \pm 0.03 * *$ & $0.7 \pm 0.07 * *$ & $0.7 \pm 0.09 * *$ & $0.8 \pm 0.04 * *$ \\
\hline
\end{tabular}

Legend: * Indicates significant stationary and spatial variation of wealth for São Luís and São José de Ribamar (p < 0.05 Kruskal-Wallis); ** Indicates significant stationary and spatial variation of equitability for São Luís and São José de Ribamar ( $\mathrm{p} 0.05$ ANOVA one-way).Source: Authors.

PCA results explained $68.7 \%$ of total variance for the samples taken in São José de Ribamar, with the sum of factors $1=42.8 \%$ and factor $2=25.8 \%$ (Figure 3 ), where the seasonality of the abiotic parameters remained well defined. PCA results explained $72.3 \%$ of the total variance for samples from the region of São Luís with the sum of factors $1=45.3$ and factor $2=$ $45.3 \%$.

Figure 3. Analysis of principal components of the zooplankton community and environmental factors from the coastal dam of (A) São Luís and (B) São José de Ribamar.
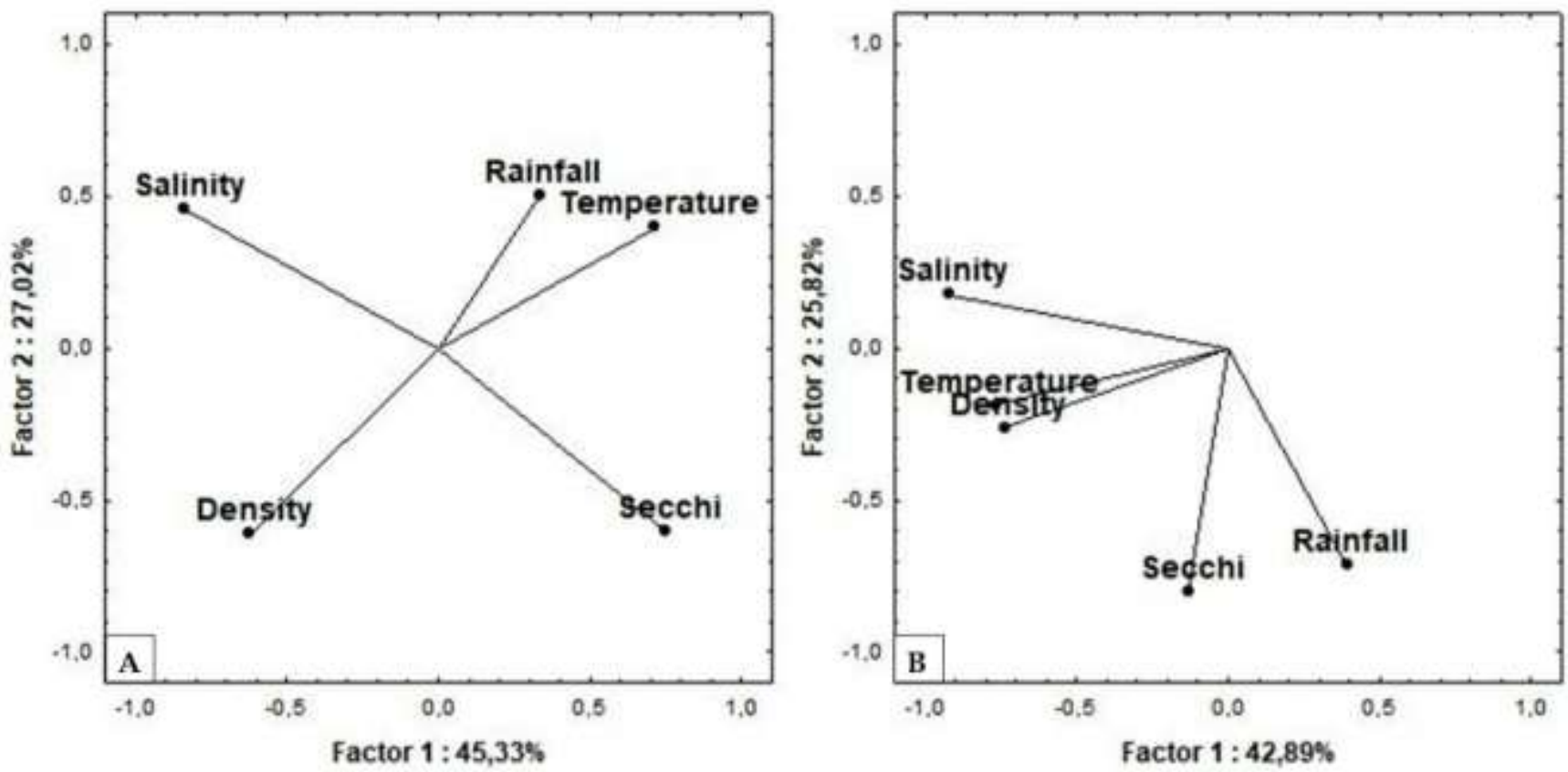

Source: Authors.

In general, the canonical correspondence analysis (CCA) explained 95.8\% of the relationship of the environment to the distribution of dominant zooplanktonic groups in the region of São Luís, while in São José de Ribamar, the CCA explained 93.8\% of the relationship (Figure 4). In the São Luís coastal dam, it was possible to notice that axis 1 of Figure 4 explained 
$70.3 \%$ of the relation between sea surface temperature, Secchi, and rainfall. All samples from the study area were positively influenced by Ammonia beccarii, Ammonia sp, Acartia lilljeborgi, Acartia tonsa, and Nauplius of copepods. For this reason, they are more subject to these environmental factors. Axis 2 of Figure 4 was less representative with 25.4\% of the relation; thereby, salinity can influence the spatial and temporal distribution of Bivalvia, Euterpina acutifrons, and Centropages velificatus in the study area. In the region of São José de Ribamar, the spatial-temporal distribution of the species A. lilljeborgi, A. tonsa, and $O$. similes were more influenced by the physical-chemical parameters of the sea surface temperature, Secchi and rain, as shown by axis 1 , which explained $86.0 \%$ of the correlations. Meanwhile, axis 2 explained that $7.8 \%$ of the ordinations of the organisms Polychaeta, Parvocalanus crassirostris, and Brachyura (zoea) were influenced by the salinity in the environment.

Figure 4. Canonical Correspondence Analysis species of zooplankton and abiotic parameters of the tide-control structures of (A) São Luís and (B) São José de Ribamar. Dry period (open ball) and rainy season (closed ball).
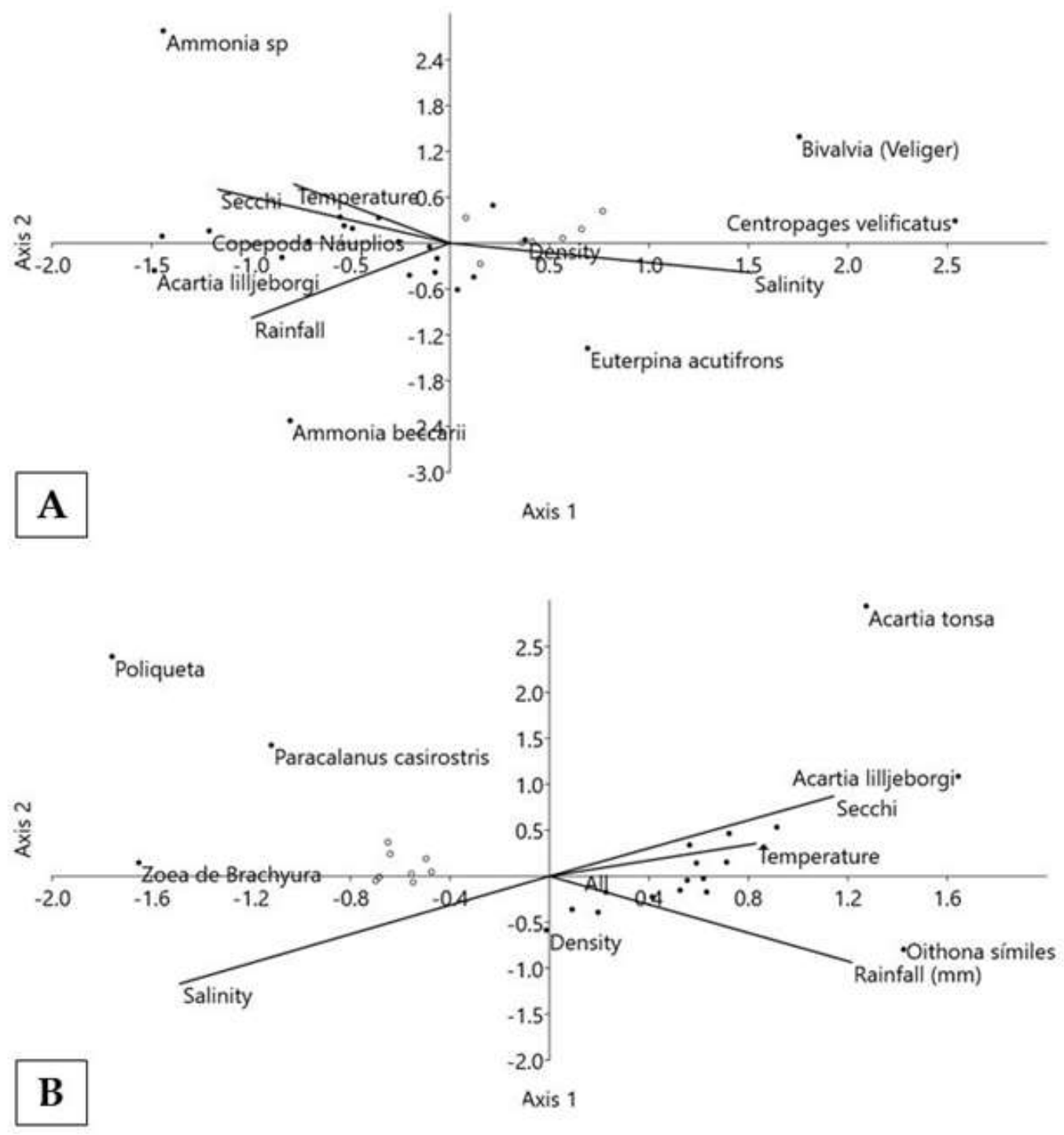

Source: Authors. 
The Cluster hierarchical classification method showed that both São Luís and São José de Ribamar had two expressive groupings during the study (Figure 5). At the São José de Ribamar coastal dam, the similarity (Figure 5) between the months studied was well represented by the points P1JAN18 and P2JAN18, which comprised the rainy period, while at the São Luís tide-control structure, the highest similarity was better explained by the rainy season samples from April (P1APR18 and P2APR18).

Figure 5. Cluster hierarchical classification methods: (A) São Luís, (B) São José de Ribamar. (1) Dry period and (2) Rainy season.
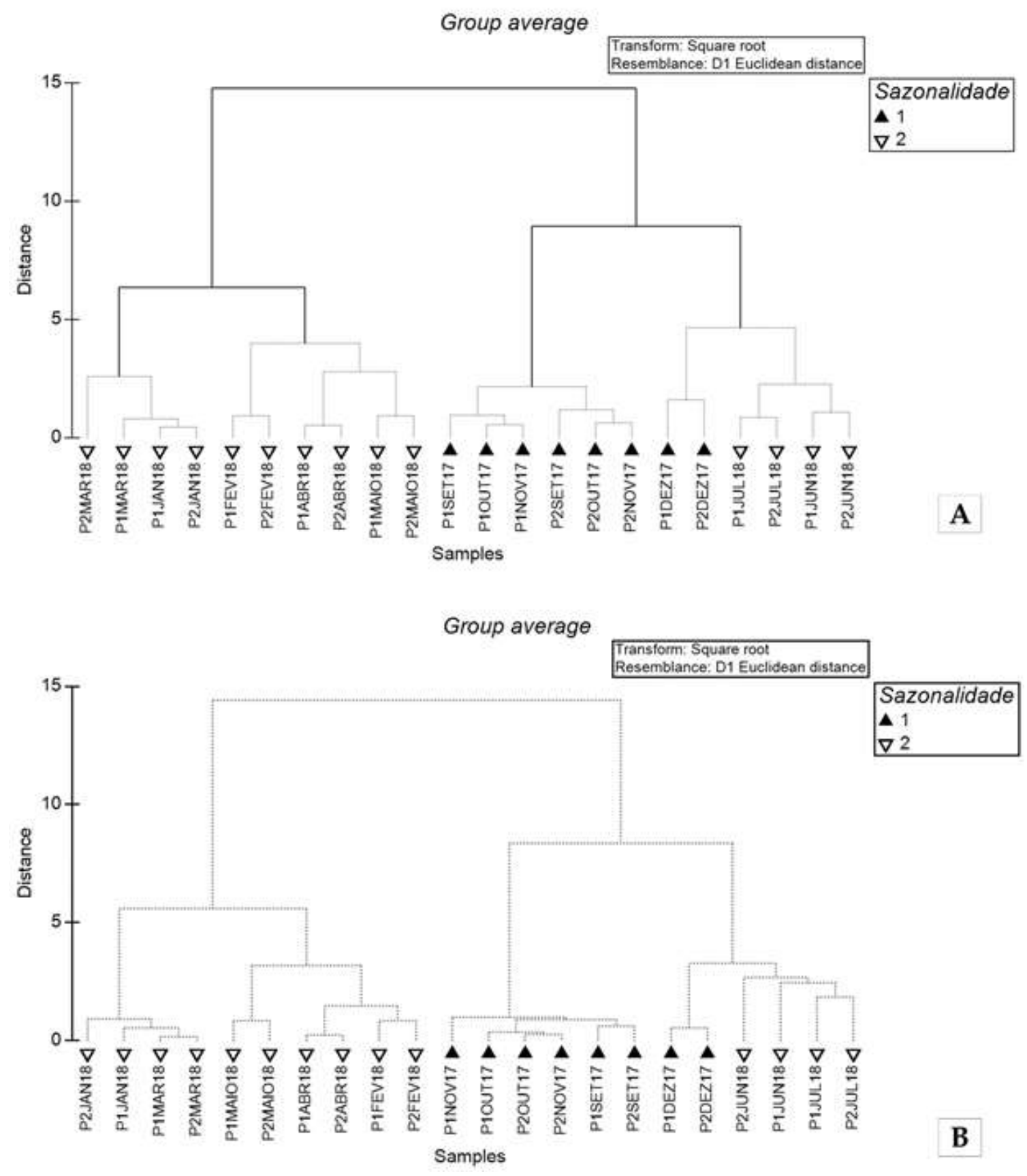

Source: Authors. 


\section{Discussion}

Surface water temperature at tidal containment structures followed the expected seasonal and spatial patterns for coastal regions, with constant values and without much variation during drought and precipitation. This reality is best identified on the coast of São José de Ribamar, as shown by Fontes et al. (2016), which identified that the region has relatively constant values. Meanwhile, at São Luís, Azevedo et al. (2008) also found a constant temperature range, mainly seasonally, with an annual average of $27^{\circ} \mathrm{C}$.

Seasonal and spatial variation of salinity was very significant $(\mathrm{p}<0.05)$, as expected, since they were probably influenced by rainfall regimes in the regions, considering that the higher the precipitation, the lower the environmental salinity rates tend to be (Santos et al., 2020). It is important to emphasize that the salinity at the sample points (p < 0.05 ANOVA oneway) also varied in the region of São Luís and São José de Ribamar, where the tide-control structures may influence not only the organisms but also some abiotic parameters.

It is well known that the island of São Luís has several substantial rivers, mainly in the Bay of São Marcos and Arraial (El-Robrini et al., 2015). Thus, the deposition of organic matter can affect the organisms in the region. It was observed that the cities of São Luís and São José de Ribamar presented two climatic seasons (dry and rainy) through the pluviometric data of the region. According to Azevedo et al. (2008), the rainy season in the Maranhense Gulf extends from January to June, while the dry season is from July to December.

The copepod A. lilljeborgi was one of the most abundant organisms in the study, revealing its preference for a set of physical-chemical conditions, such as surface water temperature, transparency, and rainfall. In studies carried out by Resgalla Júnior (2011), he identified that A. lilljeborgi has a relationship with temperature and salinity in the coastal region of Santa Catarina. Meanwhile, the A. tonsa species was one of the most common organisms during both seasonal periods and study areas. Amaral et al. (2017) and Leite et al. (2009) found a high diversity of this species along the Brazilian coast, indicating it is independent of seasonality since it tends to reproduce whenever it finds favorable oceanographic characteristics. The copepod nauplii identified in the study by Kvilea et al. (2016) were strongly influenced by physical-chemical parameters such as surface water temperature, which corroborates the results found in the São Luís and São José de Ribamar tide-control structures, through canonical correspondence analysis (CCA).

In the region of São José de Ribamar, the Brachyura (zoea) was characterized as representative indicates the dispersion and recruitment of decapod crustaceans, which may be of commercial value to local fishermen. Impacts in this region may cause a deficiency in the recruitment of these individuals in their larval stage, noting that a possible decrease in zooplankton communities may also lead to a decrease in fish stocks, as well as an ecological imbalance in the estuary or adjacent coastal region (Silva-Falcão et al., 2007; Hirose et al., 2015). Finally, trawling can also influence benthic communities in the region (Bernardes et al., 2016).

Salinity influences bivalve mollusks, mainly in the larval stage, when it interferes with their physiological process, determining feeding capacity and survival, as well as the ability to select fixation sites (Moraes et al., 2015). Meanwhile, it can affect reproduction in adulthood since they suffer stress with variations of salinities, which cause organisms to have partial or total spawning.

Boltovscoy (1999) determined in his research that planktonic communities tend to be less dense in estuarine and coastal areas than in oceanic regions, which corroborates with the present study, which found maximum values of 1.8 bits ind ${ }^{-1}$ at São José de Ribamar and 2.3 bits ind ${ }^{-1}$ in the region of São Luís. The richness of the zooplankton communities at the tidal control structures was considered low according to Margalef (1995) since they were below 5.0 bits ind $^{-1}$. These results are considered by Neumann-Leitão et al. (1995) as normal for coastal environments, especially those that are dynamic. The low number of 
studies on the composition and ecological indexes of zooplankton in regions with tidal containment makes it impossible to compare our results with other regions with the same problem.

The analysis of the similarity of the São Luís and São José de Ribamar tide-control structures shows that there was homogeneity of the zooplankton, that is, regardless of the influences of the anthropic agents, such as the tidal containment structure itself, the communities are probably able to maintain equilibrium. Finally, this study found zooplanktonic groups like those of Nunes et al. (2020) on the coast of Maranhão.

\section{Conclusion}

The physical-chemical parameters found at each tide-control structure were found to influence the zooplankton communities at São Luís and São José de Ribamar because the analyses of the ecological indexes and the one-way ANOVA showed that the most significant difference between the study areas was in the distribution patterns of the organisms. The behavior of the environmental parameters was normal for the two coastal regions studied. Finally, it is well known that tidal containment structures can impact biodiversity, and in this study, they were found to affect the distribution, density, and abundance of zooplankton communities at the tide-control structures in São Luís and São José de Ribamar. Based on the research, the waters from rivers can bring nutrients to the coastal zone, making these environments more suitable for the reproduction of fish, for example, in São Luís, where 40 taxa were found, the majority of which are ichthyoplankton. The entry of these rivers could favor this group. This could be the main characteristic that makes the points sampled in São Luís have a greater abundance of zooplankton and are taxonomically richer concerning the points of São José de Ribamar. Finally, this study reinforces the importance of monitoring zooplankton to identify ecological changes in environments.

\section{Acknowledgments}

We thank the support of the Fundação de Amparo à Pesquisa e ao Desenvolvimento Científico e Tecnológico do Maranhão, the State University of Maranhão, and finally the Laboratory of Fisheries Biology.

\section{References}

Amaral, P. T., Amaral, W. J. A., Ortiz, D. O., Agostini, V. O \& Muxagata, E. (2017). The mesozooplankton of the Patos Lagoon Estuary, Brazil: trends in community structure and secondary production. Marine Biology Research, 13, 48-61. https://doi.org/10.1080/17451000.2016.1248850

Azevedo, A. C. G., Feitosa, F. A. N. \& Koening, M. L. (2008). Distribuição espacial e temporal da biomassa fitoplanctônica e variáveis ambientais no Golfão Maranhense, Brasil. Acta Botânica Brasilica, 22(3), 870-877. https://doi.org/10.1590/S0102-33062008000300022

Barra, O. A. O. L., Arruda, A. G. F., Vasconcelos, F. P., Casemiro, M. B. \& Amaral, D. N. (2018). Aspectos legais de proteção à zona costeira no Brasil e seus desdobramentos no litoral do estado do Ceará. Estudios Socioterritoriales, 23, 83-100.

Bernardes, V. P., Sousa, N. A., Teles, J. N. \& Fransozo, A. (2016). Abundância e distribuição ecológica do caranguejo aranha endêmico Leurocyclus tuberculosus (H. Milne Edwards; Lucas, 1834) (Crustacea: Decapoda: Majoidea) em diferentes profundidades no litoral norte paulista. Ciência et Praxis, 9(17), 7-16.

Boltovskoy, D. (1999). South Atlantic Zooplankton. Backhuys Publishers, 1491p.

Bonecker, S. L. C. (2006). Atlas de zooplâncton da região central da Zona Econômica Exclusiva Brasileira. Museu nacional, 232p.

Bradford, J. M., Markhaseva, E. L., Rocha, C. E. F. \& Abiahy, B. (1999). COPEPODA. In: BOLTOVSKOY, D. (Ed.). South Atlantic Zooplankton. 860-1098 p.

Dajoz, R. (1983). Ecologia geral. Vozes, 472p.

El-Robrini, M., Marques, J. V., Silva, M. A. M. A., El-Robrini, M. H., Feitosa, A. C., Tarouco, J. E. F., Santos, J. H. S. \& Viana, J. R. (2015). Erosão e progradação do litoral brasileiro/Maranhão. Brasil, Ministério do Meio Ambiente, 44p.

Fontes, K. A. A., Lisboa, A. T. \& Castro, R. S. (2016). Macroalgas aderidas em pneumatóforos de Avicennia germinans (1.) Stearn na praia de Boa Viagem, São José de Ribamar - Maranhão. Acta tecnológica, 11(1), 425-1856. 
Hirose, G. L., Souza, L. S., Silva, S. L. R., Alves, D. F. R. \& Negreiros-Fransozo, M. L. (2015). Population structure of the red mangrove crab, Goniopsis cruentata (Decapoda: Grapsidae) under different fishery impacts: Implications for resource management. Revista de Biologia Tropical, 63(2), $443-457$.

Kvilea, K.; Langangena, Ø.; Prokopchukb, I.; Stensetha, N. C. \& Stigea, L. C. (2016). Disentangling the mechanisms behind climate effects on zooplankton. Proceedings of the National Academy of Sciences, 113(7), 1841-1846. https://doi.org/10.1073/pnas.1525130113

Leite, N. R., Pereira, L. C. C. \& Costa, R. M. (2009). Distribuição temporal do mesozooplâncton no furo Muriá, Pará, Brasil. Boletim do Museu Paraense Emílio Goeldi. Ciências Naturais, 4(2), 149-164.

Mackas, D. L., Greve, W., Edwards, M., Chiba, S., Tadokoro, K., Eloire, D., Mazzocchi, M.G., Batten, S., Richardson, A. J., Johnson, C., Head, E., Conversi, A. \& Peluso, T. (2012). Changing zooplankton seasonality in a changing ocean: Comparing time series of zooplankton phenology. Progress in Oceanography, 97, 100, 31-62. https://doi.org/10.1016/j.pocean.2011.11.005

Marcus, A. (2004). An overview of the impacts of eutrophication and chemical pollutants on copepods of the coastal zone. Zoological Studies, 43(2), 211-217.

Margalef, R. (1958). Temporal succession and spatial heterogeneity in phytoplankton. In Buzzati-Traverso, A. A. Perspectives in marine biology. Berkeley, University of California, 621p.

Margalef, R. (1995). Ecologia. Barcelona, Omega. 951p.

Masullo, Y. A. G. (2016). Evolução do processo de urbanização e alterações ambientais na praia de São Marcos, São Luís - MA. Espaço \& Geografia, 19(2), $561-595$.

Moraes, D. T., Coelho Júnior, C., Cruz, R. C. G. \& Lopes, S. G. B. C. (2015). Ocorrência e recrutamento larval de Teredinidae (Mollusca, Bivalvia) na região do Sistema Costeiro Cananéia-Iguape, São Paulo, Brasil. Iheringia, 105(1), 28-34. https://doi.org/10.1590/1678-4766201510512834

Neumann-Leitão, S., Gusmão, L. M. O., Vieira, D. A. N. \& Paranhos, J. D. N. (1995). Zooplânctons da área estuarina do Rio Formoso - PE (Brasil). Trabalhos Oceanográficos, 23(1), 55-64. https://doi.org/10.5914/tropocean.v23i1.2677

Nunes, Y. B. S., Diniz, T. S., Figueiredo, M. B., Lima, K. L. \& Silva, C. M. (2020). Distribuição das comunidades zooplanctônicas ao longo do litoral norte do Maranhão, Brasil. Brazilian Journal of Development, 6, 18416-18423. https://doi.org/10.34117/bjdv6n4-131

Nunes, Y. B. S., Silva, L. R., Mendes, E. S., Araújo, N. B. \& Figueiredo, M. B. (2018). Composição e abundância de resíduos sólidos em praias urbanas da região metropolitana da Ilha de São Luís (MA), Brasil. Revista Brasileira de Engenharia de Pesca, 11(1), 1-12. https://doi.org/10.18817/repesca.v11i1.1482

Paula, D. P. (2015). Erosão costeira e estruturas de proteção no litoral da região metropolitana de Fortaleza (Ceará, Brasil): um contributo para artificialização do litoral. Revista eletrônica PRODEMA, 9(1), 73-86. http://www.revistarede.ufc.br/rede/article/view/306

Pielou, E. C. (1966). The measure of diversity in different types of biological collections. Journal of theoretical Biology, 13, 131-144.

Porto Neto, F. F., Neumann-Leitão, S., Gusmão, L. M. O., Vieira, D. A. N., Silva, A. P. \& Silva, T. A. (1999). Variação sazonal e nictemeral do zooplâncton no canal de Santa Cruz, Itamaracá, PE, Brasil. Trabalho Oceanográfico, 27, 43-58.

Resgalla Júnior, C. (2011). The holoplankton of the Santa Catarina coast, southern Brazil. Annals of the Brazilian Academy of Sciences, 83(2), 575-588. https://doi.org/10.1590/S0001-37652011000200017

Richardson, A. J. (2008). In hot water: zooplankton and climate change. - ICES. Journal of Marine Science, 65(3), 279-295. https://doi.org/10.1093/icesjms/fsn028

Santos, A. S. S., Sousa, P. H. C., Melo, N. F. A. C., Castro, K. F. C., Pereira, J. A. R. \& Santos, M. L. S. (2020). Distribuição espaçotemporal dos parâmetros abióticos e bióticos em um estuário Amazônico (Brasil). Arquivos de Ciências do Mar, 53(1), 82 - 97. http://dx.doi.org/10.32360/acmar.v53i1.41888

Shannon, C. E. W. (1963). The Mathematical Theory of Communication. Urbana, University Illinois Press, 132p.

Silva-Falcão, E. C., Severi, W. \& Rocha, A. A. F. (2007). Dinâmica espacial e temporal de zoeas de Brachyura (Crustacea, Decapoda) no estuário do Rio Jaguaribe, Itamaracá, Pernambuco, Brasil. Iheringia, 97(4), 434-440. https://doi.org/10.1590/S0073-47212007000400012

Souza, C. A. (2019). Impactos do represamento sobre a diversidade zooplanctônica e implicações para o biomonitoramento. [Tese de Doutorado]: Universidade de Brasília, Planaltina (DF), $125 \mathrm{f}$.

Souza, C. R. G. (2009). A Erosão Costeira e os Desafios da Gestão Costeira no Brasil. Revista da Gestão Costeira Integrada, 9(1), $17-37$.

Vieira, F. S. \& Dantas, M. A. T. (2015). O protista foraminífero, bioindicador ambiental: uma abordagem para o ensino de ciências e biologia. Revista Eletrônica de Biologia, 8(1), 267-282.

Webber, M., Edwards-Myers, E., Campbell, C. \& Webber, D. (2005). Phytoplankton and zooplankton as indicators of water quality in Discovery Bay, Jamaica. Hydrobiologia, 545, 177-193. https://doi.org/10.1007/s10750-005-2676-X

Ziober, B. R. \& Zanirato, S. H. (2014). Ações para a salvaguarda da biodiversidade na construção da usina Hidrelétrica Itaipu Binacional. Ambiente \& Sociedade, $17(1), 59-78$. 